Article

\title{
Peripheral Isothermal System of Heat Gain Storage for Thermal Stability in Low-Energy Buildings
}

\author{
Arkadiusz Węglarz ${ }^{1}$, Michał Pierzchalski ${ }^{2}$ and Dariusz Heim ${ }^{3, *(\mathbb{D}}$ \\ 1 Faculty of Civil Engineering, Institute of Building Engineering, Warsaw University of Technology, al. Armii \\ Ludowej 16, 00-637 Warszawa, Poland \\ 2 Faculty of Architecture, Warsaw University of Technology, ul. Koszykowa 55, 00-659 Warszawa, Poland \\ 3 Faculty of Process and Environmental Engineering, Department of Environmental Engineering, \\ Lodz University of Technology, ul. Wolczanska 213, 90-924 Lodz, Poland \\ * Correspondence: dariusz.heim@p.lodz.pl; Tel.: +48-42-631-39-20
}

Received: 30 May 2019; Accepted: 23 July 2019; Published: 31 July 2019

check for updates

Featured Application: The results presented in the paper maybe useful for the development of heat recovery systems as well as optimisation of latent heat storage tanks.

\begin{abstract}
The problem of heat storage in low- or ultra-low-energy houses is becoming a crucial issue. The general purpose of this study was to determine the potential for utilising heat gain recovery in a building. The proposed solution is based on an auxiliary latent heat storage tank using paraffin RT24. The tank is connected to an integrated heat recovery system that supplies heat from the internal loop of a mechanical ventilation system. The storage capacity of the tank was determined using the proposed parameter "excess of heat gains" of the thermal zone, and was obtained by measurement. The detailed construction of the tank, the phase change material properties and the quantity were proposed. The data that was collected allowed for the calculation of the temporary charging level as well as the overall seasonal energy stored in the tank. It was shown that during the heating season, the temperature could rise above the set-up value of $20^{\circ} \mathrm{C}$ by as much as $8 \mathrm{~K}$ at maximum. Although the analysed building was characterised by heavy construction and high thermal mass, the additional heat could be effectively stored and utilised to cover the energy demand of the zone at the level of $88 \mathrm{MJ} / \mathrm{a}$ and $208 \mathrm{MJ} / \mathrm{a}$, depending on the airflow rate between the rooms and the heat exchanger, for 140 and $420 \mathrm{~m}^{3} / \mathrm{h}$, respectively. The expected energy effect for a low thermal mass construction, e.g., a timber frame was much higher and the results obtained by using the numerical simulation were $116 \mathrm{MJ} / \mathrm{a}$ for $140 \mathrm{~m}^{3} / \mathrm{h}$, and $273 \mathrm{MJ} / \mathrm{a}$ for $420 \mathrm{~m}^{3} / \mathrm{h}$, respectively.
\end{abstract}

Keywords: phase change materials; gain utilization factor; peak temperatures; time-shifting

\section{Introduction}

Newly constructed low-energy buildings are characterised by their ability to balance heat gain and heat loss. This follows recent improvements in the thermal insulation of interior partitions and the introduction of solutions that allow for the recovery of heat from ventilated air [1,2]. Heat gains, which are characterised by periodicity, allow not only for the temporary compensation of losses, but can also cause an increase in the air temperature in the building's interior. Limiting the overheating effect in rooms and increasing the efficiency of utilising the heat gains can be achieved by a significant increase in the building's thermal mass. It is well known that thermal mass has an effect on the building time constant [3], the time lag and the decrement factor [4,5], and finally, on the thermal stability [6] or thermal comfort of users [7]. All these factors are particularly important in the context of the prevention of overheating across climate and building use [8]. A building with an increased amount of thermal 
mass is able to time-shift and flatten out heat flow fluctuations $[9,10]$; this is referred to as the thermal inertia of a building [8]. Guglielmini et al. [11] introduce the term "passive thermoregulation effect" to describe the effect with which a building's thermal inertia is able to reduce the fluctuations of the inside air temperature.

The traditional method of increasing thermal inertia is the use of high heat density construction materials or the application of phase change materials (PCM) within the building's internal partitions. However, according to Reilly and Kinnane [12], while high thermal mass structures are likely to be effective in hot climates, in cold climates the drawbacks of high thermal mass outweigh the advantages and high thermal mass leads to an increase in energy use. These conclusions were formulated for well insulated external walls during negative heat flux at night, considering any internal partition (or other internal accumulated volume) in which the heat was stored and released to the indoor environment without external loses. The other case for internal and external heavy mass partition was considered by Karlsson et al. [13] and was tested in a cold climate. The results showed that passive energy storage through high thermal mass can significantly change the power consumption pattern, which can have significant benefits while having little influence on the total energy consumption, in most cases. Moreover, Jedrzejuk proved that in buildings with lower thermal insulation standards, the internal thermal capacity has a smaller influence on energy performance than in the case of very well insulated buildings [14]. As shown in a paper written by Sun et al. [15] and Corrado and Paduos [16], thermal storage systems should be properly optimised and designed. In [17], the authors revealed that high thermal storage walls with variable emission and absorption coatings are able to reduce the heating energy demand by $5 \%$.

One of the methods of achieving effective heat storage is utilising phase change materials [18]. Most of the research has been dedicated to modifying internal construction elements [19,20], for example, gypsum wall covering [21,22], furniture [23], or ventilated slabs [24]. The work presented by Zalba et al. [25], has shown that it is possible to integrate PCM with the building's elements, along with utilizing them in different types of storage tanks [26]. Such solutions are usually installed in technical areas and not living spaces, and can be connected to Heating, Ventilation, Air Conditioning (HVAC) systems [27]. Enclosing PCM in a container outside of living areas eliminates problems associated with toxicity and inflammability [28]. Issues concerning the choice of material and the construction of the latent heat thermal energy storage systems (LHTESS) have already been described, e.g., in [29]. Although PCM storage tanks are well described for water storage tanks for heating or hot water systems [30,31] as well as heat pumps [32], their integration with a ventilation unit has still not been adequately studied. The latest reports show that the heat can be effectively transferred through ventilated air and storage in the PCM activated concrete blocks [33]. It was proved that the ventilated tubes play the role of a regulator to unload the system, and thus heat the injected air. The main disadvantages of this solution is the total volume of the elements required for full scale building application, and construction problems. The system proposed and described in that paper does not suffer from the drawback mentioned above because it is more compatible with much higher density of thermal mass in the form of storage tank.

On the basis of the literature review it is possible to answer the question of whether heat gains should be stored within a building's internal structure, including interior partitions, or in isolated, peripheral heat tanks. The goal of the analyses presented below was to investigate the potential of storing heat gains during the winter season. The solution proposed is a peripheral heat storage tank, which is located outside the thermal boundary of building. The amount of energy stored in a day, the energy capacity of the tank and the speed of charging and discharge were taken into consideration. The analysis was conducted using an energy efficient single-family building based on real physical parameters-inside temperature and instantaneous heat gains. Excess heat gains (EHG) were assumed and served as the basis for the temporary (TEHG), seasonal (SEHG) and average values. 


\section{Heat Flows in Low-Energy Buildings}

The energy balance between heat gains (solar and internal) and heat losses in highly energy efficient or passive buildings is close to zero. During most of the heating or winter season, heat gains exceed losses and are not effectively used in the energy balance of the building. This period shows a significant increase in internal air temperature. This is particularly visible in buildings with low thermal mass, e.g., a lightweight timber frame construction. In this case, storing the excess heat is a highly reasonable means of increasing the gain utilization factor.

The authors propose a novel parameter called temporary excess heat gain. This excess refers to the thermal zone (room, group of rooms or the whole building). Its value is defined as follows:

$$
T E H G=\Delta T \times c_{p} \times \rho_{p} \times V \times \Delta t(\mathrm{~kJ})
$$

where:

$c_{p}$ - heat capacity of air $(\mathrm{kJ} / \mathrm{kgK})$;

$\rho_{p}$-air density $\left(\mathrm{kg} / \mathrm{m}^{3}\right)$;

$V$-air volume exchange between the zone and storage tank $\left(\mathrm{m}^{3} / \mathrm{h}\right)$;

$\Delta t$-period of time during heat is exchange (h);

$\Delta T$-temperature difference (K) given by the following formula:

$$
\Delta T=\left(T_{i}-T_{r}\right)(\mathrm{K})
$$

where:

$\mathrm{T}_{\mathrm{i}}$-current temperature in the building's thermal zone $(\mathrm{K})$;

$T_{r}$-reference temperature (K);

if $T_{i}>T_{S}$ then $T_{r}=T_{S}$

if $T_{i} \leq T_{s}$ then $T_{r}=T_{i-1}$

where:

$T_{s}$-current temperature of storage medium,

$T_{i-1}$ - previous air temperature in the building's thermal zone $(\mathrm{K})$;

In this article, the value of TEHG was set on the basis of real measurement data collected over 1 year for a single-family, ultra-low-energy, residential building. The value was defined using real, measurements of internal air temperature. For the same building, the LHTESS was proposed and analysed, both experimentally and numerically for two different building constructions, light and heavyweight.

The innovative heat recovery system proposed maintains a constant air temperature in the building's thermal zone. A description of the heat storage tank can be found in Section 4 of this article. The amount of heat stored in the tank was calculated according to the following assumptions. A $100 \%$ heat storage efficiency was assumed, along with the size of the tank, and allowing for an airflow in the room of up to 3 air changes per hour $\left(420 \mathrm{~m}^{3} / \mathrm{h}\right)$. Although these values are simplified, the aim of this article was not to find the heat storage potential of the tank, but rather, the potential excess heat gain in the building. Optimising the storage tank and the means of heat exchange between the airflow and the PCM closed in tubes could be a basis for further research. Due to the character of internal air temperature changes and the volume of the storage material, the amount of stored heat was limited. The results of the storage tank's temporary charge can be found in Section 5 of the article. Moreover, the amount of the seasonal heat gain available for storage and the reuse in the building was defined. 


\section{Application in an Existing Building}

The case studied in this paper is a single-family residential building built in 2015. The building is located in the village of Zielonki Wies near Warsaw in Poland. The building consists of two main blocks. The shape of the garage section is parallel to the sides of the plot, while the residential part is rotated by $19.5^{\circ}$ so that the wall with the largest amount of glazing is oriented south (Figure 1). During the winter only the residential part is air-conditioned by a continuous, heating system. The assumed indoor temperature as set on the thermostat, is $20^{\circ} \mathrm{C}$. The only available energy carrier at the site was electricity. For this reason, as well as for economic reasons, the designer used electric cables placed in a 5 -cm thick concrete floor as surface heating.

The building was designed using traditional masonry techniques. It is made of materials with a large thermal capacity: masonry walls made of lime-sand blocks, a monolithic reinforced concrete ceiling above the ground floor, and a concrete floor with an epoxy resin layer. The heat transfer coefficient of the external partitions is between 0.09 and $0.10 \mathrm{~W}\left(\mathrm{~m}^{2} \cdot \mathrm{K}\right)$. The building is mechanically ventilated, and heat is recovered from both the supply and the exhaust. The building's air-tightness assumed in the calculation was $n_{50}=0.6 \mathrm{~h}^{-1}$, while the tested air-tightness of the building envelope was $n_{50}=0.35 h^{-1}$. Parameter $n_{50}$ describes the amount of air volume exchanges through the building envelope at a pressure difference of $50 \mathrm{~Pa}$. The air-tightness of the existing building was tested by performing the Blower Door Test according to PN-EN ISO 9972:2015-10.

All the windows have external blinds, additionally the windows on the south side on the ground floor were protected from the sun by an external canopy.

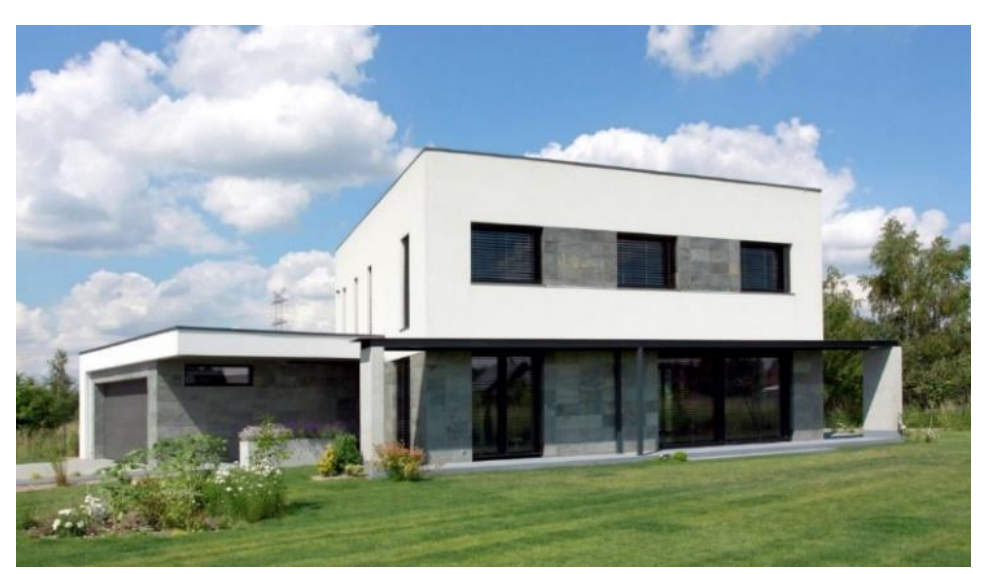

Figure 1. The case study-a single-family low energy residential building. Photo by the author.

The usable area of the residential part of the building is $187 \mathrm{~m}^{2}$, the garage and the garden room are $47 \mathrm{~m}^{2}$. The study involved a thermal zone which consisted of the rooms located on the ground floor. These include the kitchen, the dining room and the living room, with large areas of glazing on the south side. The total area of the rooms analysed is $55 \mathrm{~m}^{2}$, with an internal (net) volume of $140 \mathrm{~m}^{3}$. The plan of the ground floor with the rooms considered in this study (marked in red) is shown in Figure 2.

The heating energy demand obtained with the steady-state method was $12.2 \mathrm{kWh} / \mathrm{m}^{2} \mathrm{a}$. The calculated final energy demand for heating amounted to $2974.6 \mathrm{kWh}$ per year. The air tightness $\mathrm{n}_{50}$ at a level of $0.6 \mathrm{~h}^{-1}$ was assumed in the calculations. 


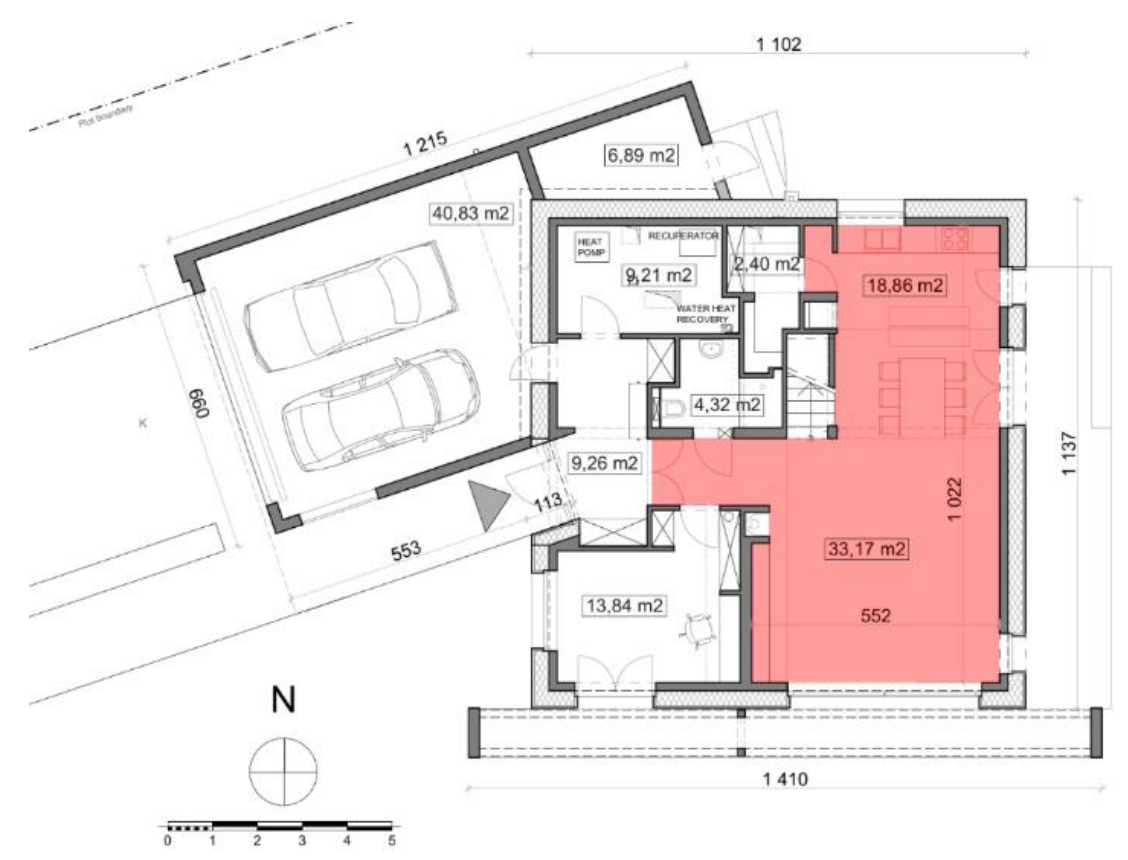

Figure 2. Ground floor plan. The analysed rooms were marked in red-the kitchen and dining room, and living room. Source: Drawing made by the author.

A BMS (building management system) was installed in the building in order to monitor climate parameters and energy consumption in the building. The measurements of the BMS system were registered from September 2016, and were recorded in 10-min intervals. The BMS system records weather parameters such as: external temperature $\left({ }^{\circ} \mathrm{C}\right)$, average wind speed $(\mathrm{m} / \mathrm{s})$, maximum wind speed $(\mathrm{m} / \mathrm{s})$, dominant wind direction $(\mathrm{N}, \mathrm{E}, \mathrm{S}, \mathrm{W}, \mathrm{NE}, \mathrm{SE}, \mathrm{SW}, \mathrm{NW})$, light intensity $(\mathrm{lx})$, precipitation (logic value $\mathrm{y} / \mathrm{n}$ ), air relative humidity $(\%)$ and air pressure (hPa). In addition to the weather data, the following parameters were recorded: the consumption of electricity for external and internal lighting, energy consumption to supply the heat recovery unit, heating (separately for individual rooms), domestic hot water (DHW) and the internal temperature in individual rooms.

An exemplary series of data recorded from 15 February, 2018 to 2 March, 2018 is presented in Figure 3. Heating load (W) indicates that the actual temperature in the room was less than the temperature set on the thermostat (assumed indoor temperature) and thus the heating system was activated. Even during the period when the heating system was turned off, the indoor temperature exceeded $20^{\circ} \mathrm{C}$, and occasionally it even reached $28^{\circ} \mathrm{C}$. These temperature increases are the result of excess heat gains occurring in the zone. Periodic overheating can be limited by effective heat storage and the stored energy can be reused later to cover heating energy demand. The theoretical amount of energy stored during the heating season was calculated on the basis of the measurement data and it is presented in Section 5. 


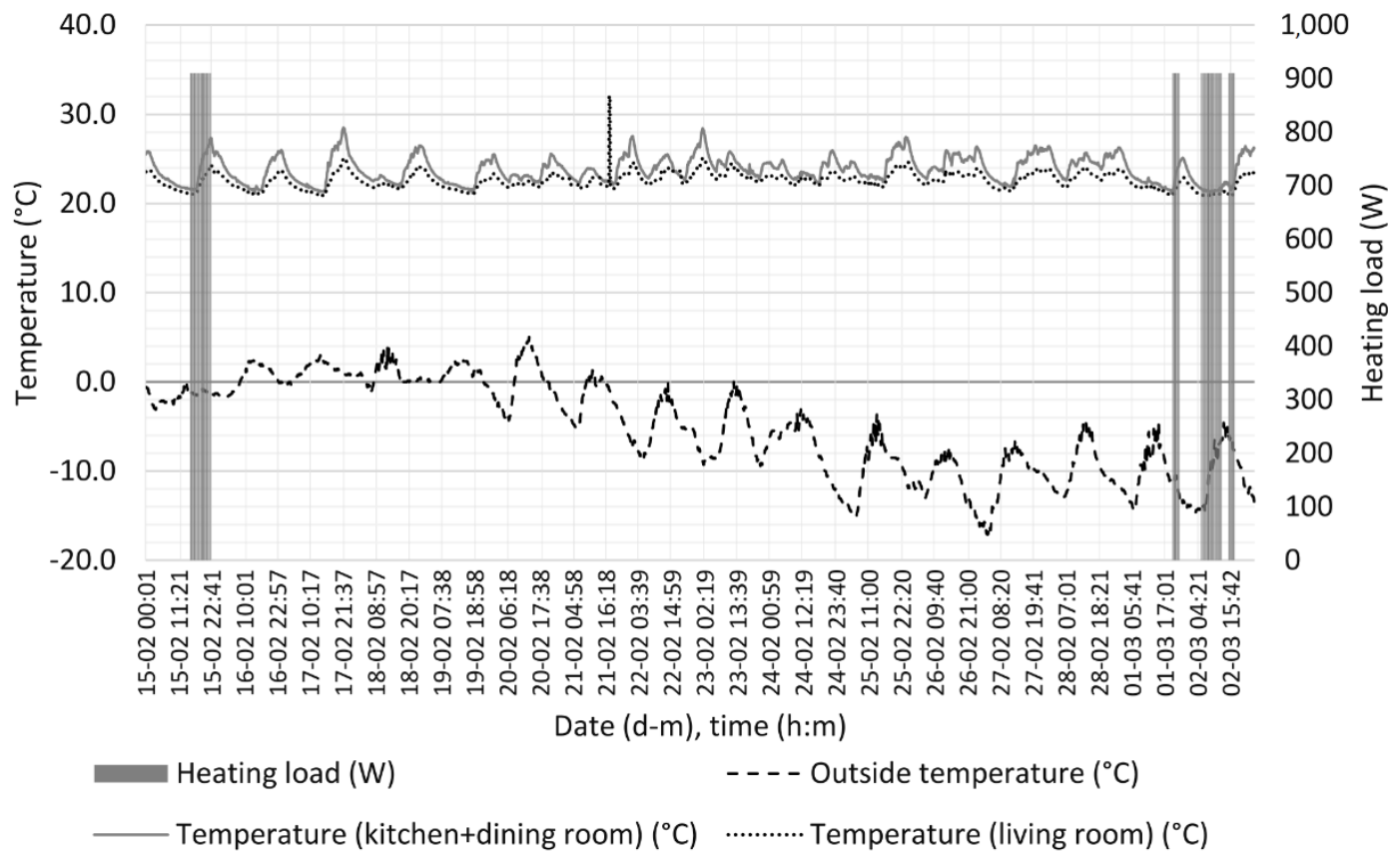

Figure 3. An exemplary series of data recorded from 15 February, 2018 to 2 March, 2018.

\section{Peripheral Heat Storage Tank with PCM}

The idea of using the PCM tank for air distribution with air ducts or a mechanical ventilation system is not a new solution. However, in most cases the system has been used for cooling and takes advantage of a discounted electricity tariff during the night-time through peak shaving [34]. Free cooling with latent-heat thermal energy storage can also be used as an alternative to night-ventilation [35]. The design of the energy storage system was based on storage tanks used in solar collectors. Moreover, the design of the heat storage system makes the following assumptions:

- The storage tank should be light and constructed from materials that are easily available in the market.

- The system should be capable of circulating air 3 times within an hour.

- The selected phase change material should store heat for as long as the time it would take the temperature in the monitored rooms to fall below a level that would normally turn the heating system on.

Taking these requirements into account, the phase change material was chosen first. The phase change material used in the analysis is paraffin RT24. The melting area is $21-25^{\circ} \mathrm{C}$, with a peak at $24^{\circ} \mathrm{C}$. The total phase change range for the material is from 16 to $31^{\circ} \mathrm{C}$. However, for our study the useful range is from 21 to $26^{\circ} \mathrm{C}$. The enthalpy characteristics for the specific temperature range is presented in Figure 4. The total amount of latent heat that can possibly be accumulated between 20.5 and $26.5^{\circ} \mathrm{C}$ is $104 \mathrm{~kJ} / \mathrm{kg}$. The other properties are as follows: heat conductivity $0.2 \mathrm{~W} /\left(\mathrm{m}^{2} \cdot \mathrm{K}\right)$, and density $880 \mathrm{~kg} / \mathrm{m}^{3}$ (solid state) and $770 \mathrm{~kg} / \mathrm{m}^{3}$ (liquid state). The reason for choosing this phase change material was its thermal characteristics, particularly its enthalpy in the given temperature range. Paraffin RT24 is characterized by having the highest heat storage capacity in the $23.5-24.5^{\circ} \mathrm{C}$ range. According to the manufacturer (Rubitherm $\mathrm{GmbH}$, Berlin, Germany), the total heat storage capacity for the range of $20.5-26.5{ }^{\circ} \mathrm{C}$ is $104 \mathrm{~kJ} / \mathrm{kg}$ and makes up $65 \%$ of its total value at $160 \mathrm{~kJ} / \mathrm{kg}$ [36]. 


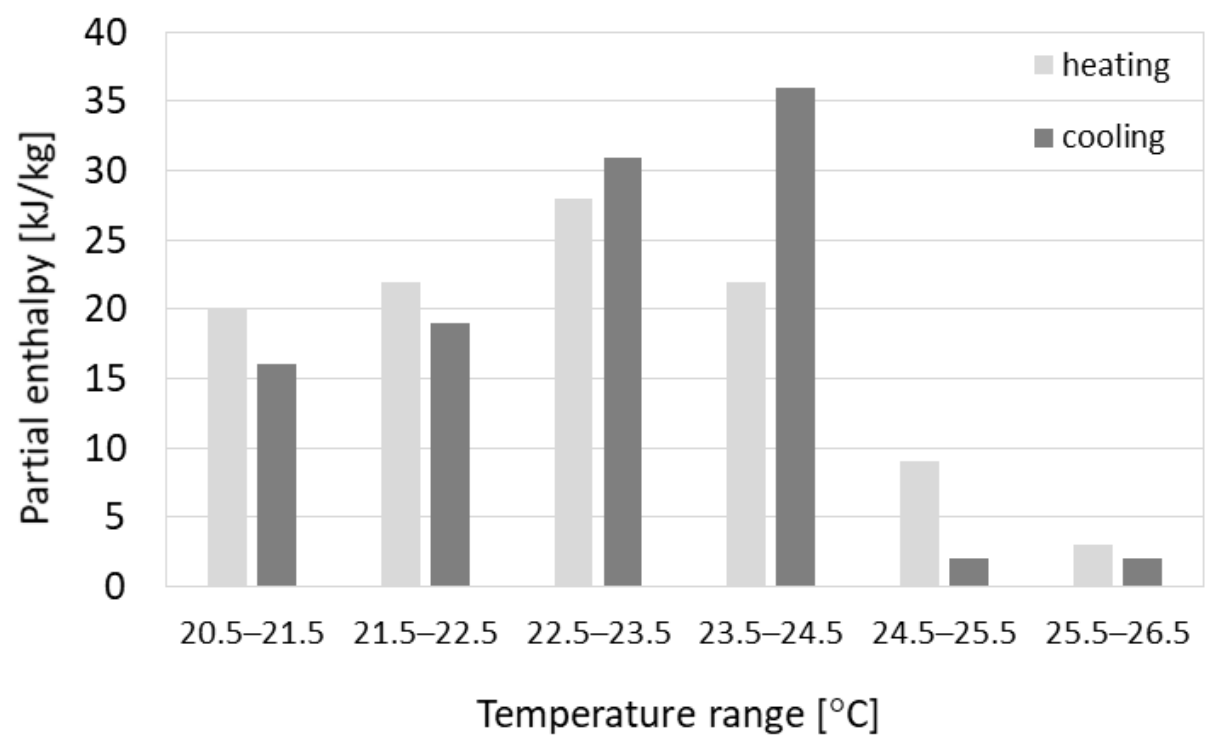

Figure 4. Partial enthalpy for the specific temperature range.

Then, we defined the method for dynamically simulating the minimal capacity of the heat storage to capture excess heat from unexpected heat gains (more sunny days in winter or using the fireplace instead of electric heating), and store it until it is needed for heating the monitored rooms. Subsequently, the required volume of the phase change material was calculated. The length of the rods was chosen so that they would contain a predefined amount of phase change material in an arrangement that enabled the free flow of air.t The length of the copper rods was the basis for deciding the size of the oblong cylinder.

The authors proposed a novel heat gain storage system in the peripheral PCM tank, the scheme of which can be seen in Figure 5. The installation consists of an air intake, a turbine with a maximal airflow of $420 \mathrm{~m}^{3} / \mathrm{h}$, which corresponds to 3 air changes per hour for the living area (living room and kitchen), a PCM heat storage, air ducts, an acoustic damper, and an air exhaust in the living room. The heat storage tank was designed as a cylinder built from two steel plate shells, filled with polyurethane or aerogel thermal insulation. The external diameter of the cylinder is $54 \mathrm{~cm}$ and the length is $80 \mathrm{~cm}$. The internal envelope was fitted with steel rods and 137 of 20-mm copper tubes filled with PCM were fitted to them. To optimally use the volume of the tank, 8 additional $15-\mathrm{mm}$ tubes were placed inside. The length of all tubes is $61 \mathrm{~cm}$. The top and bottom of the cylinder were constructed and insulated like the sides of the cylinder. Two $160-\mathrm{mm}$ stub pipes were placed in the geometrical centre of the circle. The total volume of PCM is $0.027 \mathrm{~m}^{3}$, while the maximum energy capacity of the storage tank is $848 \mathrm{~kJ}$.

The storage tank works through the airflow in the container and the copper pipes are filled with PCM. Unidirectional flow is achieved thanks to the turbine controlled by the BMS. The duration and speed of rotation is chosen so that heat is absorbed from the air and stored in the PCM while the average air temperature in the kitchen, the living room and the dining room is at least $1 \mathrm{~K}$ higher than the temperature set on the thermostat, despite the heating system being turned off. When the temperature in the room falls below the temperature on the thermostat, the recovery heat from the storage tank is used. Later, when the PCM tank is discharged, the heating system turns on. The installation is equipped with an acoustic damper so that the airflow can barely be heard. 


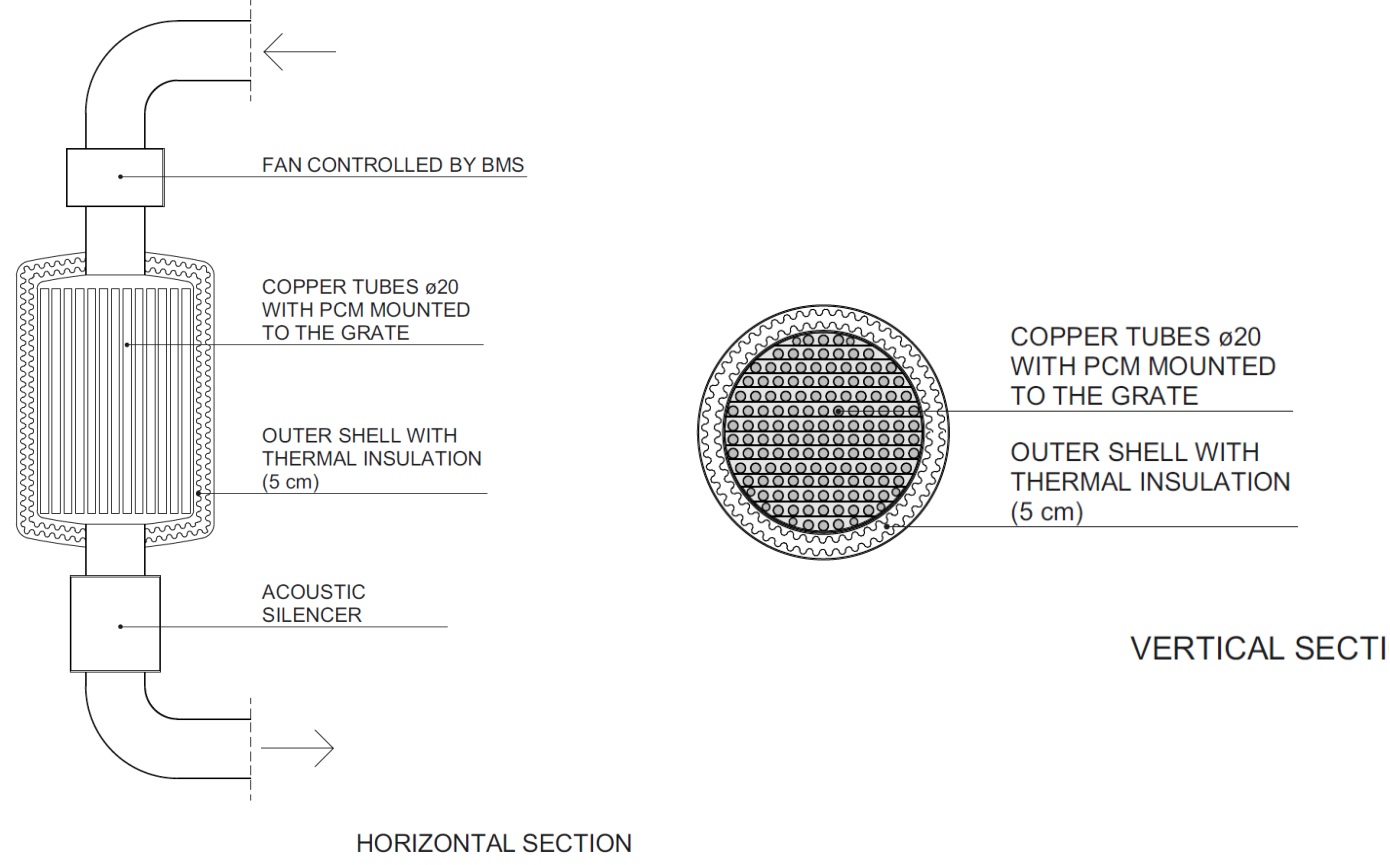

(a)

(b)

Figure 5. The scheme of the phase change material storage tank installation with heat exchanger:

(a) Horizontal cross section; (b) Vertical cross section.

\section{Theoretical Effectiveness of the PCM Storage Tank}

The analysis of the stored heat gain was conducted for three rooms of the building described in Section 3: the kitchen, the dining and living room. The calculations presented below were performed using real data from measurements conducted between February 2017 and February 2018. For the entire period, excess heat gain (SEHG) was defined as the sum of all temporary heat gains. According to Equation (1), TEHG is positive if the temperature increases during a single time step with respect to the previous time step and the temperature is higher than the base temperature $\left(20^{\circ} \mathrm{C}\right)$. The assumption is made that it is possible to accumulate excess heat gain and utilise it later. The device filled with RT24 described in Section 4 was used in the storage tank. The SEHG values achieved in the entire heating season can be seen in Figure 6, except for the intervals when they were equal to 0 . The values were defined in 10-min time steps. The average TEHG value for the entire heating season was $19.3 \mathrm{~kJ}$.

It is important to note that these values only refer to the three rooms that belong in the day zone of the building. Figure 7 shows the temporary level of charge of the PCM storage tank. Maximal values are the result of limiting the energy capacity of the storage tank, set as $848 \mathrm{~kJ}$ and achieved independently during the time period. As seen in Figure 7, the storage tank is effectively used throughout the entire duration of the analysis period, particularly in the winter months from December to February. The changes show that the storage tank is regularly charged and discharged, with hardly any periods when it is not in use. The period of zero values in March is due to no measurement data as a result of faulty measuring equipment. The total amount of heat stored and released into the room is dependent on the assumed airflow. The value of SEHG achieved during the heating season is $88 \mathrm{MJ}$ assuming an airflow of $140 \mathrm{~m}^{3} / \mathrm{h}$, which corresponds to air exchange only in the kitchen and the living room. Increasing the airflow to the maximal throughput of exchanger $\left(420 \mathrm{~m}^{3} / \mathrm{h}\right)$, improves the stored energy potential to $208 \mathrm{MJ}$, which corresponds to an electricity reduction of $33 \%$. 


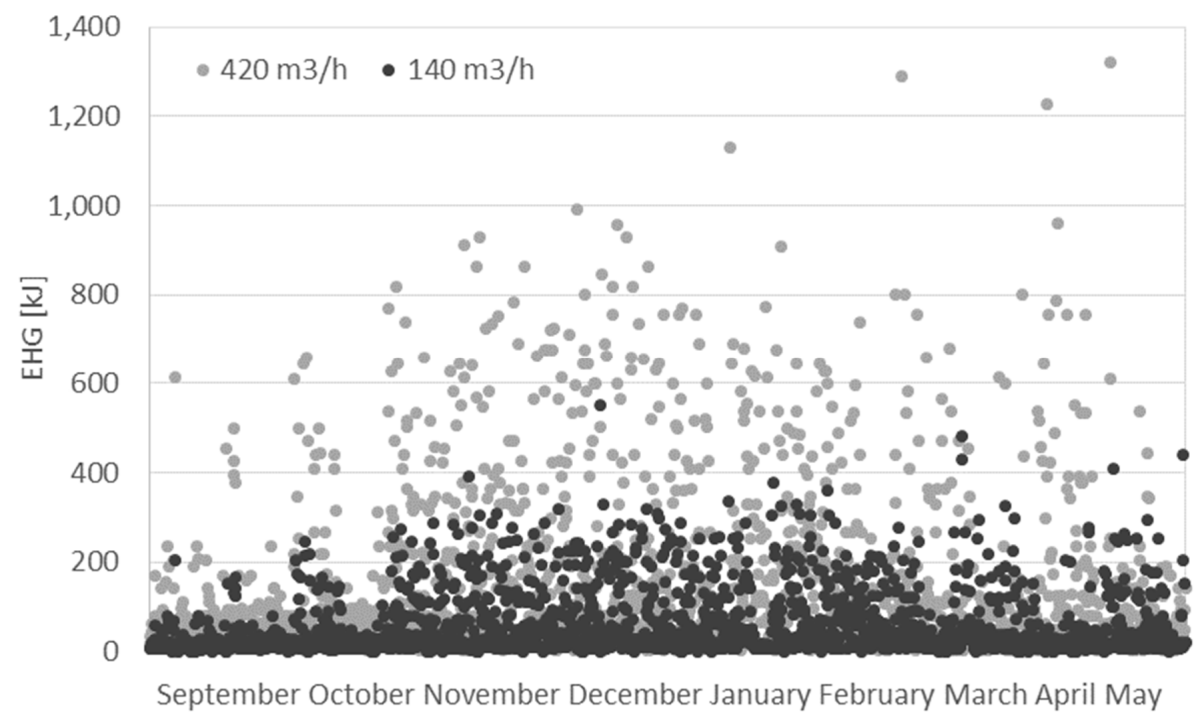

Figure 6. Excess of heat gains during the analysed heating season for different airflow rates.

The temperature history of the PCM in the storage tank is presented in Figure 8. It can be noticed that material is working above $21^{\circ} \mathrm{C}$ which is the set point that is determined by the indoor temperature. The container is charged or the energy can be regained when the indoor temperature is above the set point. The maximum value of the PCM temperature is below $26^{\circ} \mathrm{C}$. This means that the material is not overloaded during the whole period of time that was analysed. This is confirmed by the results presented in Figure 9. The melting fraction of PC is below, but almost 1.0. The lower limit is around 0.45. This is an effect of the PCM temperature in the tank, which is above $21^{\circ} \mathrm{C}$. In that case, some of the paraffin is melted.

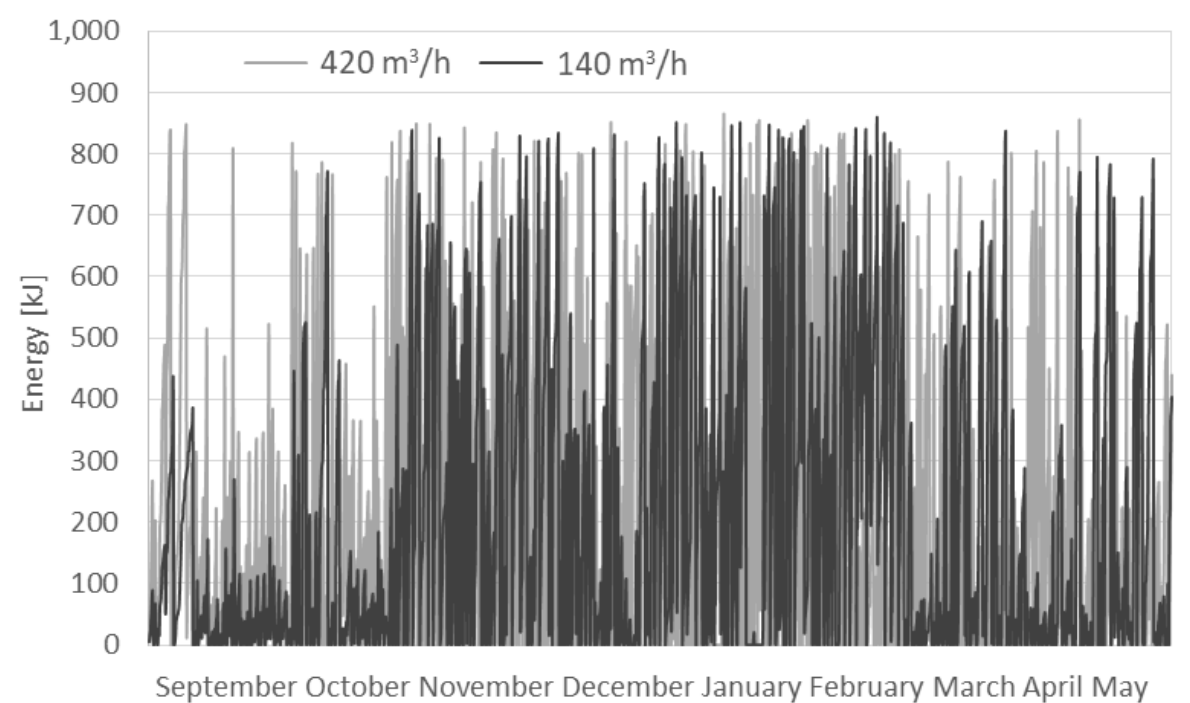

Figure 7. Temporary charging/discharge of the storage tank for different airflow rates. 


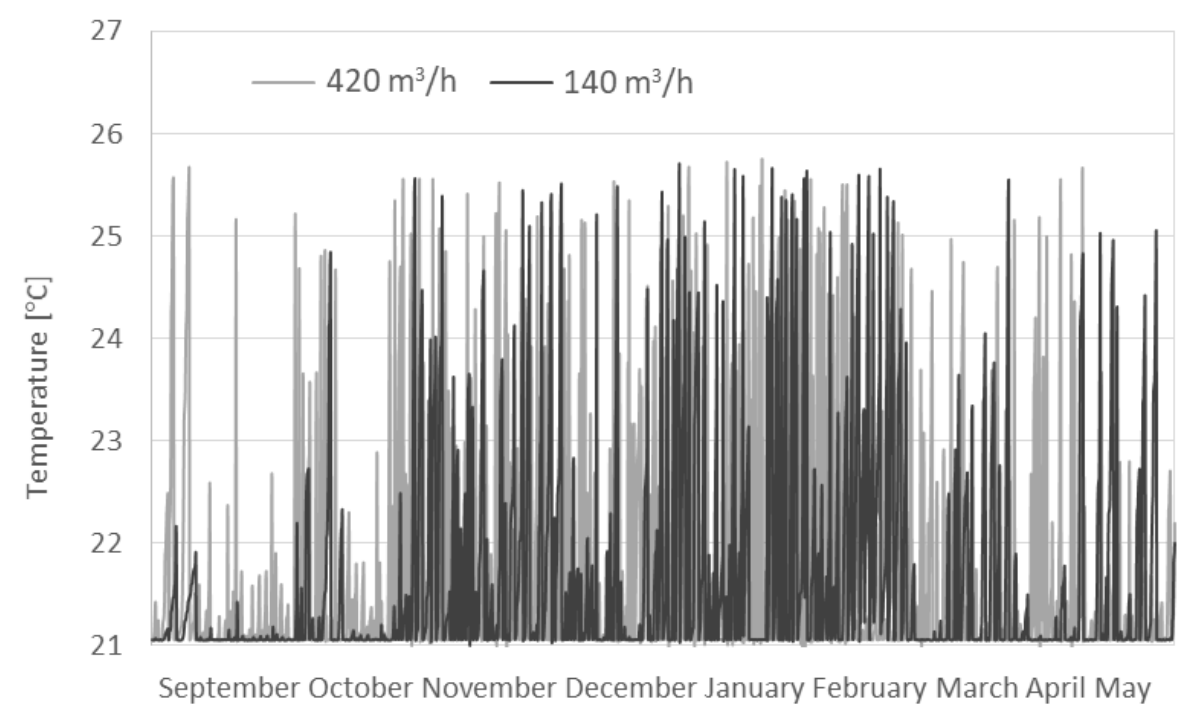

Figure 8. Temperature of the PCM in the storage tank for different airflow rates.

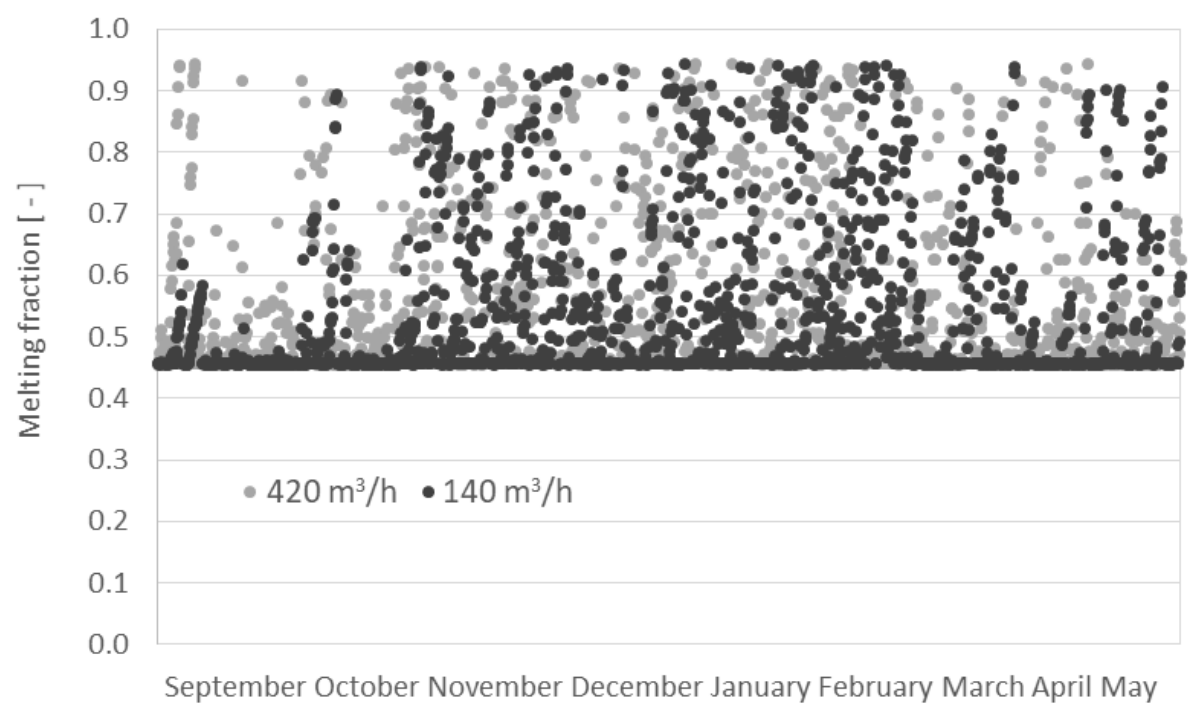

Figure 9. Melting fraction of the PCM in the storage tank for different airflow rates.

An additional study was devoted to a numerical analysis of the analysed building and other scenarios. This analysis enabled us to determine the heat gain storage potential for other building construction solutions, including timber frame constructions (low thermal mass). It is expected that the efficiency of heat gain storage in lightweight construction buildings will be much higher than in the case of heavily constructed buildings. For the comparative analysis, the results from the building energy performance simulation was used. A model of the existing building was developed in the simulation programme Design Builder (uses the EnergyPlus dynamic simulation engine), in accordance with the actual state, that is, a heavy construction. An airflow of $140 \mathrm{~m}^{3} / \mathrm{h}$ between the heat storage unit and the rooms was assumed. The calculation model was calibrated so that the SEHG values achieved from the simulation and real measurement data were the same. The calibration was done by choosing an appropriate heat gain scenario. The calculations were performed using a 1-hour time step for climate data for a typical meteorological year at the location of the existing building. The next calculation was performed for a building with a light construction, in which massive masonry walls, concrete slabs, floors and ceilings were substituted with an entirely timber construction. The calculations were repeated using the lightweight construction building model. The obtained SEHG was $116 \mathrm{MJ}$, and an average TEHG of $23.9 \mathrm{~kJ}$. Assuming a maximum air throughput in the exhaust at 3 air changes per 
hour for the analysed room $\left(420 \mathrm{~m}^{3} / \mathrm{h}\right)$, the SEHG value was $273 \mathrm{MJ}$. In comparison with the heavily constructed building, the value of SEHG increased by about $30 \%$.

\section{Conclusions}

This study investigates the possibility of storing internal heat gains to stabilise internal air temperatures during the heating or cold season. A method for defining excess heat gains (temporary TEHG and seasonal SEHG) on the basis of internal temperature measurement data from a thermal zone with controlled environment parameters was proposed. The proposed technical solution was a small peripheral heat storage tank connected to the air ventilation circuit using phase change materials. The energy potential of this solution was defined on the basis of measurement data from a passive, ultra-low-energy building, with a heavy construction in continental climate conditions.

The proposed peripheral heat storage tank connected with a heat exchanger contained $0.027 \mathrm{~m}^{3}$ of phase change material, RT24. The analysis of energy efficiency showed that a storage tank designed in this way could effectively store short-term internal heat gains from the building's zone. Charging and discharging of the storage tank occurred practically in a 24-hour cycle, and in the winter season it achieved full charge on multiple occasions. The house was designed to minimize overheating of the building in the summer, for example, the southern canopy is used to protect the windows from direct solar radiation. Due to the change in the sunlight angle of incidence during the year, direct solar radiation penetrates into the interior in winter, which is utilised as an additional heat gain. In such a situation, the indoor temperature may increase and users open the window causing losses of unused energy. For these reasons, in today's homes it is helpful to encourage residents to appropriate behaviour of so that they have an impact on final energy consumption.

The paper analysed an ultra-low-energy building under continental climatic conditions. Based on the measurement data from the BMS, the yearly energy consumption for three rooms was $156.4 \mathrm{kWh} / \mathrm{a}$ (563.0 MJ/a). By using the proposed heat recovery system combined with a thermal storage tank, the yearly energy savings are $51.9 \mathrm{kWh} / \mathrm{a}(187.0 \mathrm{MJ} / \mathrm{a})$, or around $33 \%$. This device has the additional task of ensuring proper thermal comfort. In building with high air tightness and low energy demand for heating, any additional heat gains, e.g., resulting from the recreational use of the fireplace, result in excessive temperature increases. In the summer, this type of device complements the systems that increase the protection against overheating.

The proposed solution is related to a specific case, however, it shows the potential of employing this type of storage tank, especially in energy efficient and passive buildings where temporary (even during the heating/cold season) heat gains significantly exceeded heat losses. The expected energy effect could be much higher in the case of timber frame constructions with a much lower thermal inertia. Based on the simulation analysis, the achieved differences in SEHG values between a heavy and a lightweight building were about $30 \%$. It is important to keep in mind that a building with different energy characteristics might require adjusting the parameters of the heat storage tank, including its size and the amount of PCM used.

Although similar solutions have been applied to the storage of thermal energy from solar collectors, this paper proposes an innovative method for their future use.

Author Contributions: Concept formulation, literature review, D.H.; evolution of overarching research goals and aims, D.H. \& A.W.; conducting measurement and data analysis, M.P.; resources, investigation, calculation, data curation and visualisation, M.P. \& A.W.; development of heat storage tank concept and construction, A.W.; writing —original draft preparation, review and editing, ALL.

Funding: This research received no external funding. The APC was funded by Politechnika Warszawska.

Conflicts of Interest: The authors declare no conflict of interest. 


\section{References}

1. Kurnitski, J.; Feldmann, C.; Heiselberg, P.; Mazzarella, L.; Sartori, I.; Voss, K.; Wahlström, Å. Present Energy Performance Requirements and nZEB Targets in Some Selected Countries. In Green Energy and Technology; Springer: London, UK, 2013; pp. 31-46. ISBN 978-1-4471-5609-3.

2. Firlag, S. How to meet the minimum energy performance requirements of Technical Conditions in year 2021 ? Procedia Eng. 2015, 111, 202-208. [CrossRef]

3. Nowoświat, A.; Pokorska-Silva, I. The Influence of Thermal Mass on the Cooling off Process of Buildings. Period. Polytech. Civ. Eng. 2018, 62, 173-179. [CrossRef]

4. Asan, H.; San, Y.S. Effects of Wall's thermophysical properties on time lag and decrement factor. Energy Build. 1998, 28, 159-166. [CrossRef]

5. Ulgen, K. Experimental and theoretical investigation of effects of wall's thermophysical properties on time lag and decrement factor. Energy Build. 2002, 34, 273-278. [CrossRef]

6. Strzałkowski, J.; Garbalińska, H. Thermal simulation of building performance with different loadbearing materials. IOP Conf. Ser. Mater. Sci. Eng. 2018, 415, 012014. [CrossRef]

7. Kisilewicz, T. Performance of building materials and whole enclosures in non-stationary thermal conditions. Procedia Eng. 2015, 108, 445-452. [CrossRef]

8. Verbeke, S.; Audenaert, A. Thermal inertia in buildings: A review of impacts across climate and building use. Renew. Sustain. Energy Rev. 2018, 82, 2300-2318. [CrossRef]

9. Fadejev, J.; Simson, R.; Kurnitski, J.; Bomberg, M. Thermal mass and energy recovery utilization for peak load reduction. Energy Procedia 2017, 132, 39-44. [CrossRef]

10. Heim, D.; Pawłowski, M. The Methodology of Thermal Energy Management for Nearly Zero Energy Buildings. Period. Polytech. Civ. Eng. 2019, 63, 499-517. [CrossRef]

11. Guglielmini, G.; Magrini, U.; Nannei, E. The Influence of the Thermal Inertia of Building Structures On Comfort and Energy Consumption. J. Therm. Insul. 1981, 5, 59-72. [CrossRef]

12. Reilly, A.; Kinnane, O. The impact of thermal mass on building energy consumption. Appl. Energy 2017, 198, 108-121. [CrossRef]

13. Karlsson, J.; Wadsö, L.; Öberg, M. A conceptual model that simulates the influence of thermal inertia in building structures. Energy Build. 2013, 60, 146-151. [CrossRef]

14. Jesdrzejuk, $\mathrm{H}$. The influence of building zones with different dynamic properties on the building energy performance. IOP Conf. Ser. Mater. Sci. Eng. 2018, 415, 012045. [CrossRef]

15. Sun, C.; Shu, S.; Ding, G.; Zhang, X.; Hu, X. Investigation of time lags and decrement factors for different building outside temperatures. Energy Build. 2013, 61, 1-7. [CrossRef]

16. Corrado, V.; Paduos, S. New equivalent parameters for thermal characterization of opaque building envelope components under dynamic conditions. Appl. Energy 2016, 163, 313-322. [CrossRef]

17. Hoes, P.; Hensen, J.L.M. The potential of lightweight low-energy houses with hybrid adaptable thermal storage: Comparing the performance of promising concepts. Energy Build. 2016, 110, 79-93. [CrossRef]

18. Khadiran, T.; Hussein, M.Z.; Zainal, Z.; Rusli, R. Advanced energy storage materials for building applications and their thermal performance characterization: A review. Renew. Sustain. Energy Rev. 2016, 57, 916-928. [CrossRef]

19. Memon, S.A.; Cui, H.; Lo, T.Y.; Li, Q. Development of structural-functional integrated concrete with macro-encapsulated PCM for thermal energy storage. Appl. Energy 2015, 150, 245-257. [CrossRef]

20. Pomianowski, M.; Heiselberg, P.; Jensen, R.L. Full-scale investigation of the dynamic heat storage of concrete decks with PCM and enhanced heat transfer surface area. Energy Build. 2013, 59, 287-300. [CrossRef]

21. Oliver, A. Thermal characterization of gypsum boards with PCM included: Thermal energy storage in buildings through latent heat. Energy Build. 2012, 48, 1-7. [CrossRef]

22. Sharifi, N.P.; Shaikh, A.A.N.; Sakulich, A.R. Application of phase change materials in gypsum boards to meet building energy conservation goals. Energy Build. 2017, 138, 455-467. [CrossRef]

23. Johra, H.; Heiselberg, P. Influence of internal thermal mass on the indoor thermal dynamics and integration of phase change materials in furniture for building energy storage: A review. Renew. Sustain. Energy Rev. 2017, 69, 19-32. [CrossRef]

24. Sun, X.; Chu, Y.; Medina, M.A.; Mo, Y.; Fan, S.; Liao, S. Experimental investigations on the thermal behavior of phase change material (PCM) in ventilated slabs. Appl. Therm. Eng. 2019, 148, 1359-1369. [CrossRef] 
25. Zalba, B.; Marín, J.M.; Cabeza, L.F.; Mehling, H. Review on thermal energy storage with phase change: Materials, heat transfer analysis and applications. Appl. Therm. Eng. 2003, 23, 251-283. [CrossRef]

26. D'Avignon, K.; Kummert, M. Experimental assessment of a phase change material storage tank. Appl. Therm. Eng. 2016, 99, 880-891. [CrossRef]

27. Yamaha, M. Thermal Energy Storage Tanks Using Phase Change Material (PCM) in HVAC Systems. In Two Phase Flow, Phase Change and Numerical Modeling; Ahsan, N.N.E.-A., Ed.; IntechOpen: Rijeka, Croatia, 2011; p. 24.

28. Mclaggan, M.S.; Hadden, R.M.; Gillie, M. Flammability assessment of Phase Change Material wall lining and insulation materials with different weight fractions. Energy Build. 2017, 153, 439-447. [CrossRef]

29. Agyenim, F.; Hewitt, N.; Eames, P.; Smyth, M. A review of materials, heat transfer and phase change problem formulation for latent heat thermal energy storage systems (LHTESS). Renew. Sustain. Energy Rev. 2010, 14, 615-628. [CrossRef]

30. Lafri, D.; Semmar, D.; Hamid, A.; Ouzzane, M. Experimental investigation on combined sensible and latent heat storage in two different configurations of tank filled with PCM. Appl. Therm. Eng. 2019, 149, 625-632. [CrossRef]

31. Lu, S.; Zhang, T.; Chen, Y. Study on the performance of heat storage and heat release of water storage tank with PCMs. Energy Build. 2018, 158, 1770-1780. [CrossRef]

32. Moreno, P.; Castell, A.; Solé, C.; Zsembinszki, G.; Cabeza, L.F. PCM thermal energy storage tanks in heat pump system for space cooling. Energy Build. 2014, 82, 399-405. [CrossRef]

33. Laaouatni, A.; Martaj, N.; Bennacer, R.; Lachi, M.; El Omari, M.; El Ganaoui, M. Thermal building control using active ventilated block integrating phase change material. Energy Build. 2019, 187, 50-63. [CrossRef]

34. Yamaha, M.; Misaki, S. The Evaluation of Peak Shaving by a Thermal Storage System Using Phase-Change Materials in Air Distribution Systems. HVACER Res. 2006, 12, 861-869.

35. Arkar, C.; Medved, S. Free cooling of a building using PCM heat storage integrated into the ventilation system. Sol. Energy 2007, 81, 1078-1087. [CrossRef]

36. RT24 Data Sheet. Available online: https://www.rubitherm.eu/media/products/datasheets/Techdata_-RT24_ EN_06082018.PDF (accessed on 17 July 2019).

(C) 2019 by the authors. Licensee MDPI, Basel, Switzerland. This article is an open access article distributed under the terms and conditions of the Creative Commons Attribution (CC BY) license (http://creativecommons.org/licenses/by/4.0/). 